hydrolysed, at first to $\alpha$-1.6-linked oligosaccharides of panose type on their non-reducing ends by the amylo-(1.4)-glucosidase action of the amylase, and the oligosaccharides formed therein to be further hydrolysed by this panose-hydrolysing action.

We are indebted to Dr. K. Shibasaki, of Tohoku University, for supplying the isomaltose and panose used in this work.

Osaka Municipal Technical

Yoshio Tsujisaka Research Institute,

Institute of Polytechnics,

JUIChIRo FUKUMOTO

TAKEHIKO YAMAMOTO

Osaka City University.

'Kitahara, K., and Kurushima, M., J. Ferment. Tech. (Japan), 27, 254 (1949); Mem. Res. Inst. Food Sci., Kyoto Univ., 3, 15 (1952).

2 Phillips, L. L, and Caldwell, M. L., J. Amer. Chem. Soc., 73, 3559 3563 (1951).

s. Okazaki, H., J. Agric. Chem. Soc. (Japan), 29, 181 (1955); Areh. Biochem. Biophys., 63, 322 (1956).

+4 shubert, E., Melliand Text. Acta, No. 8, 1 (1954).

${ }^{5}$ Tsujisaka, Y., and Fukumoto, J., Sci. Indust. (Japan), 30, 130, 398 $(1956)$.

${ }^{8}$ Durrum, E. L., J. Amer. Chem. Soc., 73, 4875 (1951).

" ["rderkofler, L. A., and Roy, D. K., Cereal Chem., 28, 18 (1951)

- lamasaki, I., and Ueda, S., J. Agric. Chem. Soc. (Japan), 24, 181 (1951).

- Ceda, S., Bull. Agric. Chem. Soc. (Japan), 20, 148 (1956).

\section{Degradation of Steroidal Sapogenins to 16-Dehydropregnan-20-ones}

THE need for improving the reactions whereby steroidal sapogenins, now in abundant supply, are transformed into pregnane derivatives has recently been re-emphasized ${ }^{1}$. Earlier publications have dealt definitively with the entire sequence, so that the original Marker procedure has now been improved at each stage ${ }^{2}$.

A modification offered here converts the sapogenin to its corresponding 16-dehydropregnan-20-one acetate, generally in 50-75 per cent yield of isolable product, without the necessity of separating any intermediates or changing the character of the reaction medium along the way. For example, $88 \mathrm{gm}$. of tigogenin was heated $25 \mathrm{~min}$. with $450 \mathrm{~cm} .^{3}$ of acetic anhydride; $30 \mathrm{gm}$. of pyridine hydrochloride was added and heating continued for $3 \mathrm{hr}$. The mixture was cooled to $15^{\circ} \mathrm{C}$., diluted with $50 \mathrm{~cm}^{3}$ of acetic acid and $79 \mathrm{~cm}^{3}$ of water and stirred while adding $54 \mathrm{gm}$. of chromic anhydride in $500 \mathrm{~cm}^{3}$ of 90 per cent acetic acid. The temperature was maintained at $16-20^{\circ} \mathrm{C}$. After standing at $25^{\circ} \mathrm{C}$. for $3 \mathrm{hr}$. the solution was treated first with $31.5 \mathrm{gm}$. of 36 per cent formaldehyde and then with $80 \mathrm{gm}$. of sodium acetate. The stirred suspension was heated on the steam-bath for $1 \mathrm{hr}$., cooled in ice and diluted gradually with $3,000 \mathrm{~cm}^{3}$ of cold water. A white, granular precipitate was collected, washed and dried; it melted at $120-150^{\circ} \mathrm{C}$., weighed $82 \cdot 1 \mathrm{gm}$. and by ultra-violet absorption contained 73 per cent of the 16-dehydropregnane. It was adsorbed from benzene on to fifteen parts of silica gel and the product eluted directly with 5 per cent ethyl acetate in benzene to give $51.6 \mathrm{gm}$. or 68 per cent of $3 \beta$-acetoxy-16-dehydro$5 \alpha$-pregnan-20-one (melting point $162-167^{\circ} \mathrm{C}$., $\varepsilon_{\max .(240 \mathrm{~m} \mu)} 9,300$ in methanol). When recrystallized twice from methanol, material of anslytical quality (molting point $168 \cdot 0-169 \cdot 2^{\circ}$ C., $[\alpha]_{D} 37.5^{\circ}$ (chloroform)), $\varepsilon_{\max }(240 \mathrm{~m} \mu) 9,460$ (soe ref. 3), was obtained in an overall yield of 45 per cent (value extrapolated from smaller sample).
In other instances the initial heating with acetic anhydride has been omitted; also with smaller quantities the usual ether extraction of the final mixture has been used. Thus, $20 \mathrm{gm}$. of a mixture of ruscogenin and its $\mathrm{C}_{25}$ epimer gave $20.6 \mathrm{gm}$. of extractable material of which $11.2 \mathrm{gm}$. (59 per cent vield) of the desired 16-dehydropregnane, a glass ${ }^{4}$ $\left(\varepsilon_{\max }(240 \mathrm{~m} \mu) 9,460\right)$ was obtained by direct elution with 5 per cent ethyl acetate. Hecogenin treated in the same manner yielded 59 per cent of crystalline $3 \beta$ - acetoxy - 16 - dehydro - $5 \alpha$ - pregnan $-12,20$ - dione, (melting point $179-185^{\circ} \mathrm{C}$.) from the eluates.

This method offers the advantages of speed and simplicity. It has been applied as a matter of routine to sapogenins and derivatives with uniform success.

\section{G. P. MUELLER}

Division of Chemical Research,

G. D. Searle and Company,

Skokie, Illinois. July 15.

${ }^{1}$ Chakravarti, D., Chakravarti, R. N., and Mitra, M. N., Nature, 179 1188 (1957).

Wall, M. E., Kenney, H. E., and Rothman, E. S., J. Amer. Chem. Soc., 77, 5665 (1955). Cameron, A. F. B., Evans, R. M., Hamlet. J. C., Hunt, J. S., Jones, P. G., and Long, A. G., J. Chem. Soc. 2807 (1955). 3ato, Y., Katz, A., and Mosettig, E., J. Amer. Chem. Soc, 74, 538

- Lapin, H., and Sannie, C., Bull. Soc. Chim., 1552 (1955).

\section{A Rapid and Specific Muthod for the Isolation of Pneumococcal Polysaccharide}

THe report by Gessler et al. ${ }^{1}$ on the use of a com. pletely substituted ethane (trichlorotrifluoro ethane, 'Genetron 113' ; obtained from the Division of Allied Dye and Chemical Corp., General Chemicals, Inc., New York) as a 'deproteinizing' agent in the purification of influenza virus, suggested to us that this solvent might have many uses. In particular, we were concerned with 'deproteinizing' bacterial cells with the consequent release of polysaccharides. In view of the observation that this solvent is not miscible with water and that pneumococcal polysaccharide is soluble in water, the following experiment was performed.

D. pneumoniae, typo I, smooth-phase cells were grown on beef heart infusion agar, harvested in $18 \mathrm{hr}$., washed several times and the concentration optically adjusted to $10^{8}$ cells per millilitre of buffered saline, $p \mathrm{H} 7 \cdot 2$.

One part of cells to three parts of solvent were agitated for ten minutes in the high-speed homogenizer at maximum speed, removed and then centrifuged at 1,500 r.p.m. for $10 \mathrm{~min}$. Three layers resulted : (1) an upper aqueous layer, (2) a middle gel-like layer, and (3) a bottom layer of solvent. The upper water layer was removed and treated as above for three more successive solvent extractions. During such treatment further gel-like material was removed.

The final water layer was tested for immunological activity by use of the interfacial-precipitin test using antiserum prepared against whole smooth cells. A positive reaction resulted immediately upon contact.

After concentration by evaporation in a dialysis casing with a fan, it was determined that the material extracted was strongly Molisch-positive, ninhydrinnegative and upon paper electrophoresis showed no indications of containing protein. Moreover, ultraviolet absorption tests did not indicate any absorption 